\title{
Developmental Expression of Muscarinic Cholinergic Receptors and Coupling to Phospholipase C in Rat Sweat Glands Are Independent of Innervation
}

\author{
Michael P. Grant $\mathbf{t}^{1,2}$ and Story C. Landis ${ }^{2}$ \\ Departments of ${ }^{1}$ Pharmacology and ${ }^{2}$ Neurosciences, Case Western Reserve University, School of Medicine, Cleveland, \\ Ohio 44106
}

During development, the innervation of rat sweat glands undergoes a striking change from noradrenergic to cholinergic function. The acquisition of secretory responsiveness by the glands is temporally correlated with the appearance of cholinergic properties. In addition, responsiveness fails to appear in the absence of innervation. To investigate the basis of the onset of functional transmission and secretory responsiveness and its possible relationship to innervation, we analyzed the development of muscarinic cholinergic receptors in sweat glands, examined their expression in the glands of adult rats sympathectomized at birth, and assayed the ability of muscarinic agonists to increase phosphoinositide (PI) turnover. Autoradiographic and in situ hybridization analysis revealed that muscarinic ligand binding sites were first detectable as glands begin to form on postnatal day 4 (P4). Between P4 and P14, receptor concentration increased in parallel with $m R N A$ for the $m 3$ receptor subtype. On P14, the concentration of ligand binding sites approached adult levels, although only a small proportion of glands at this age secrete in response to nerve stimulation or cholinergic agonists. When the pharmacological properties of muscarinic receptors in sweat glands of adult rats sympathectomized at birth were compared to those of normal glands, the concentration and affinity determined with [ $\mathrm{N}$-methyl-3 $\mathrm{H}$ ]-scopolamine and the $K_{i}$ values determined with the subtype-selective muscarinic antagonists 4-DAMP, pirenzepine, and AF DX-116 were similar. In addition, the moJecular subtype was unchanged as was the level of $\mathrm{m} 3$ message. Studies of PI turnover in response to muscarinic stimulation indicated that the receptors expressed in sweat glands isolated from sympathectomized and acutely denervated, as well as control, rats were functionally coupled to phospholipase $\mathrm{C}$. The absence of sympathetic innervation therefore does not appear to influence either the development of muscarinic receptors or their coupling to PI turnover.

\footnotetext{
Received Mar. 29, 1991; revised June 19, 1991; accepted June 27, 1991.

We thank Dr. George Dubyak for his helpful discussions concerning the phosphoinositide turnover experiments and competition data and Dr. Ruth Siegel for her assistance with the in situ hybridization experiments. We also thank Dr. Steven Jones for his assistance with data analysis and review of the manuscript. This work was supported by NIH Grant NS 23678 and NIDDK Grant P30 27651 to S.C.L. M.P.G. was supported by NIH Grant GM07382-14.

Correspondence should be addressed to Michael P. Grant, Department of Neurosciences, Case Western Reserve University, School of Medicine, 10900 Euclid Avenue, Cleveland, OII 44106-4975.

Copyright (C) 1991 Society for Neuroscience 0270-6474/91/113772-11\$05.00/0
}

Our results suggest that functional sympathetic cholinergic innervation plays a central role in the development and maintenance of secretory function at a step distal to signal transduction across the cell membrane.

Relatively little is known about developmental interactions between autonomic neurons and their target tissues and how such interactions may influence the subsequent development of the target cell. This is in marked contrast to our extensive knowledge of the effects of motor neurons on the development of skeletal muscle (e.g., Kullberg et al., 1977; Brenner and Sakmann, 1983; Mishina et al., 1986; Gu and Hall, 1988). One of the most thoroughly studied autonomic systems is the development of chick heart and its parasympathetic innervation. Muscarinic receptors appear early in the development of the chick heart, prior to vagal innervation and before the onset of physiological activity (Pappano and Loffelholz, 1974; Galper et al., 1977). The onset of muscarinic responsiveness, the inhibition of adenyl cyclase, is correlated with the appearance of two guanine nucleotide-binding proteins that appear several days after parasympathetic innervation arrives (Halvorson and Nathanson, 1984; Liang et al., 1986). These observations suggest that the acquisition of functional responsiveness is not regulated by the expression of muscarinic receptors, but by the expression of the appropriate G-protein. Although the time course of events is consistent with a neural role in inducing responsiveness, it has been difficult to dissect the role of cholinergic innervation in this developmental process.

Rat eccrine sweat glands provide an interesting system to study the relationship between innervation and the development of physiological responsiveness. Concentrated in rat footpads, sweat glands are innervated by cholinergic sympathetic neurons. In both adult and developing rats, sweat secretion exhibits a muscarinic pharmacology; nerve-evoked sweating is blocked by muscarinic antagonists, and secretion is elicited by local or systemic injection of muscarinic agonists (Hayashi and Nakagawa, 1963; Stevens and Landis, 1987). The muscarinic receptor expressed by the glands is the $\mathbf{M}_{2}$ glandular pharmacological subtype and corresponds to the $\mathrm{m} 3$ molecular subtype (Grant et al., 1991). Sweat glands and their innervation develop postnatally. On postnatal day $2(\mathrm{P} 2)$, numerous shallow invaginations are evident in the epidermis of the developing footpads; these rapidly elongate and form presumptive secretory tubules by $\mathrm{P} 7$ (Landis and Keefe, 1983). By the middle of the second postnatal week, the forming gland has begun to coil, and at P14 morpho- 
logically differentiated myoepithelial and secretory cells are present. On P14, a minority of glands ( $<1 \%)$ secrete in response to both nerve stimulation and injection of muscarinic agonists, but by the end of the third postnatal week most glands respond (Stevens and Landis, 1987). Although the mature gland innervation is cholinergic, during development the innervation initially expresses noradrenergic properties(Landis and Keefe, 1983; reviewed in Landis, 1990). When sympathetic fibers first reach the forming glands on $\mathrm{P} 4$, they possess catecholamine histofluorescence that is no longer detectable after the third postnatal weck. In contrast, ChAT, the synthetic enzyme for $\mathrm{ACh}$, is first detectable on P11 and continues to increase with further development (Leblanc and Landis, 1986). Additionally, the developing sweat gland innervation acquires immunoreactivity for two neuropeptides, vasoactive intestinal peptide (VIP) and calcitonin gene-related peptide (CGRP), during the first three postnatal weeks (Landis and Fredieu, 1986; Landis et al., 1988).

Several lines of evidence suggest that cholinergic innervation regulates physiological responsiveness of rat sweat glands. First, the development of the secretory response is correlated temporally with the appearance of cholinergic function; nerve-evoked sweating is detectable in a minority of rat pups on P16, shortly after development of cholinergic properties, and only glands that respond to nerve stimulation respond to administration of cholinergic agonists (Stevens and Landis, 1987). Sweat secretion even in developing rats is sensitive to muscarinic but not adrenergic agents. Second, when the innervation of sweat glands and the time course of the change in neurotransmitter function are delayed approximately $7-10 \mathrm{~d}$ by treating rat pups on $\mathrm{P} 2$ with a single injection of 6-hydroxydopamine (6-OHDA), the development of the physiological responsiveness of the glands is similarly delayed (Stevens and Landis, 1988). Finally, sweat glands of adult rats sympathectomized at birth and of adult rats and mice acutely denervated by sciatic nerve section do not sweat in response to the administration of cholinergic agonists (Hayashi and Nakagawa, 1963; Kennedy and Sakuta, 1984; Kennedy et al., 1984; Stevens and Landis, 1987; Grant et al., 1991).

To learn more about how innervation may regulate function in autonomic target tissues, we have analyzed the development of muscarinic cholinergic receptors in sweat glands and examined the ability of muscarinic agonists to stimulate the metabolism of phosphoinositides (PIs) in slices of adult sweat gland. Both muscarinic binding sites and message for the $m 3$ receptor appear early in development, prior to the differentiation of morphologically distinct cell types in the glands. Binding sites and message reach adult levels by P14, when only a small proportion of glands responded to nerve stimulation or agonist administration. Neither the concentration, the affinity, nor the molecular subtype of muscarinic receptor expressed by adult rat sweat glands was affected by neonatal sympathectomy. Furthermore, muscarinic stimulation of sweat gland slices isolated from chronically sympathectomized and acutely denervated animals produced increases in the concentration of total inositol phosphates similar to those observed in slices from normal glands. Our results suggest that functional sympathetic cholinergic innervation plays a central role in regulating both the development and the maintenance of secretory function at a point distal to the expression of muscarinic receptors and their coupling to PI turnover.

Preliminary reports of these studies have appeared previously (Grant and Landis, 1989, 1990).

\section{Materials and Methods}

Materials. Carbamylcholine atropine sulfate, choral hydrate, pilocarpine, oxotremorine sesquifumarate, dithiothreitol (DTT), acetic anhydride, 6-hydroxydopamine, triethanolamine, dextran sulfate, bovine serum albumin, ssDNA, and yeast $t$ RNA were obtained from Sigma (St. Louis, MO). Pirenzepine and 4-diphenylacetoxy- $N$-methylpiperidine methiodide (4-DAMP) were purchased from Research Biochemical Inc. (Natick, MA). AF DX-116 was the kind gift of Boehringer Ingelheim (Ridgefield, CT). Vasoactive intestinal polypeptide was kindly provided by Dr. Richard Zigmond (Department of Neurosciences, Case Western Reserve University). Terminal deoxynucleotidyl transferase was obtained from Bethesda Research Labs. [ $N$-methyl- $\left.{ }^{3} \mathrm{H}\right]$-scopolamine ( $\left.\left.{ }^{3} \mathrm{H}\right] \mathrm{NMS} ; 85 \mathrm{Ci} / \mathrm{mmol}\right),{ }^{35} \mathrm{~S}$-deoxyadenosine $5^{\prime}$-[ $\alpha$-thio]triphosphate $(1320 \mathrm{Ci} / \mathrm{mmol}$ ), and Formula 963 were from New England Nuclear (Boston, MA). Photographic emulsion NTB-3, D-19 developer, and fixer were from Kodak (Rochester, NY). Anti-bromodeoxyuridine (anti$\mathrm{BrdU}$ ) mouse monoclonal antibody was from Becton Dickson (Mountain View, CA). All other reagents were obtained from Fisher and were at least reagent grade or better.

Animals. Litters and adult ( $>6$ weeks) Sprague-Dawley rats were obtained from Zivic-Miller (Zelienople, PA). Some rats were chemically sympathectomized as neonates by treatment with 6-hydroxydopamine (6-OHDA); rat pups were injected with $100 \mathrm{mg} / \mathrm{kg} \mathrm{6-OHDA}$ in $0.9 \%$ sodium chloride containing $1 \mathrm{mg} / \mathrm{ml}$ sodium ascorbate subcutaneously daily during the first postnatal week and again on postnatal day 12. This treatment eliminates cholinergic sympathetic innervation of rat sweat glands as well as noradrenergic sympathetic innervation of peripheral target tissues (Yodlowski et al., 1984). In some adult animals, sweat glands were denervated as in the accompanying article (Grant et al., 1991).

Muscarinic receptor assays. The concentration and affinity of muscarinic binding sites were determined as described in the accompanying article (Grant et al., 1991). The localization of muscarinic binding sites was examined and receptor density quantitated in light microscopic autoradiograms (Grant et al., 1991). The molecular subtype of muscarinic receptor was determined using subtype-specific probes in in situ hybridization studies (Grant et al., 1991).

Immunocytochemistry. Immunocytochemical localization of bromodeoxyuridine (BrdU) was used to identify dividing cells in developing sweat glands (Gratzner, 1982; Nowakowski et al., 1989). Rat pups were injected intraperitoneally with $100 \mu \mathrm{g} / \mathrm{gm}$ BrdU. After $2 \mathrm{hr}$, they were killed with ether inhalation and perfused with $4 \%$ paraformaldehyde in $0.1 \mathrm{~m}$ phosphate buffer, $\mathrm{pH}$ 7.3. The rear footpads were fixed for an additional $45 \mathrm{~min}$, rinsed in buffer, and equilibrated with $30 \%$ sucrose in phosphate buffer overnight. Ten-micron cryostat sections were mounted on gelatin-coated slides, rinsed with phosphate buffer, incubated for $20 \mathrm{~min}$ in $2 \mathrm{M} \mathrm{HCl}$, washed three times in phosphate buffer, and then incubated with a mouse monoclonal antibody that recognizes BrdU in phosphate buffer containing $1 \%$ Tween-20 for $1 \mathrm{hr}$ at room temperature in a humid chamber. Following incubation, the sections were rinsed and incubated for $2 \mathrm{hr}$ with fluorescein isothiocyanateconjugated goat anti-mouse immunoglobulin. The sections were rinsed mounted in glycerol/PBS $(1: 1)$, and examined.

Phosphoinositide assay. Metabolism of phosphoinositides was determined by measuring the accumulation of total ${ }^{3} \mathrm{H}$-inositol phosphates using a protocol similar to those described previously (Berridge et al., 1982; Gil and Wolfe, 1985). Rat footpad tissue was dissected free of the dermis and epidermis and divided into four $300-400 \mu \mathrm{m}$ slices, which were collected in PBS at $4^{\circ} \mathrm{C}$. The slices were placed in microfuge tubes containing $1 \mu \mathrm{Ci}$ of ${ }^{3} \mathrm{H}$-myoinositol in $50 \mu \mathrm{l}$ of incubation buffer (in mM: glucose, $10 ; \mathrm{NaCl}, 123 ; \mathrm{KCl}, 5 ; \mathrm{MgCl}_{2}, 1.3 ; \mathrm{KH}_{2} \mathrm{PO}_{4}, 1.4 ;$ $\mathrm{NaHCO}_{3}, 26$ ), gassed with $95 \% \mathrm{O}_{2}, 5 \% \mathrm{CO}_{2}$ at $37^{\circ} \mathrm{C}$, and preincubated for $30 \mathrm{~min}$. Ten minutes prior to stimulation, an aliquot of $\mathrm{LiCl}$ was added to achieve a final concentration of $10 \mathrm{~mm}$. Pilocarpine or carbachol was added to a final volume of $250 \mu \mathrm{l}$ of the appropriate concentration and incubated for $60 \mathrm{~min}$ at $37^{\circ} \mathrm{C}$. The incubation was terminated by the addition of $930 \mu \mathrm{l}$ of a chloroform/methanol/concentrated $\mathrm{HCl}(200: 100: 1)$ mixture, and the suspension was allowed to stand for $15 \mathrm{~min}$. An additional $310 \mu \mathrm{l}$ of $\mathrm{H}_{2} \mathrm{O}$ and $310 \mu \mathrm{l}$ of chloroform were added, and the mixture was then vortexed and centrifuged. The aqueous phase $(750 \mu \mathrm{l})$ was removed to a test tube containing $10 \mathrm{ml}$ of water, and the solution was poured over a Bio-Rad mini column prepacked with $1 \mathrm{ml}$ of AG 1-X8 (formate form, 100-200 mesh; Bio-Rad) mixed $1: 1(\mathrm{w} / \mathrm{v})$ with $\mathrm{H}_{2} \mathrm{O}$. The column was washed with $50 \mathrm{~mm}$ sodium 

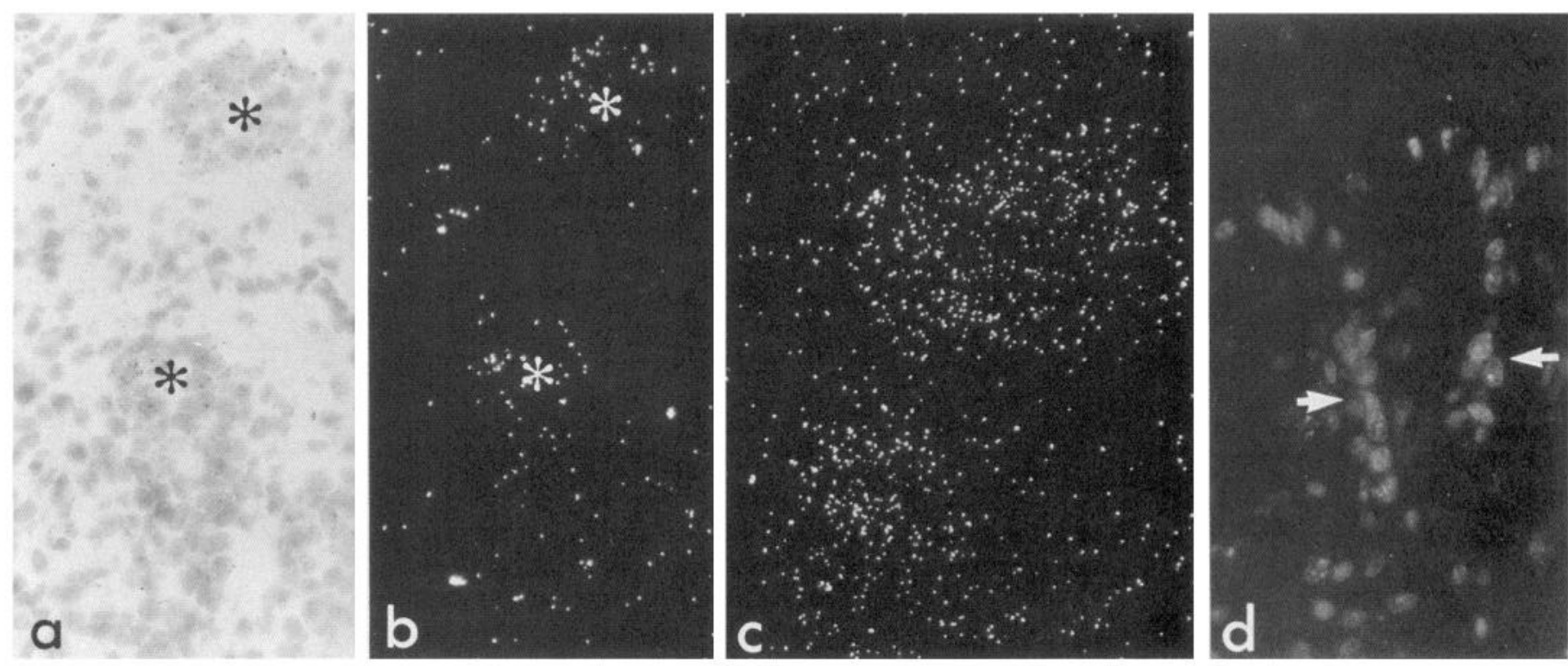

Figure 1. Early development of muscarinic receptors. $a$ and $b$, Following in situ hybridization with an ${ }^{35}$-labeled m3-specific probe to sections of P4 developing rat footpad, two developing epidermal invaginations (asterisks) are shown in bright-field (a); when the same field is examined in dark-field $(b)$, grains are evident over the invaginations. Following incubation with $\left[{ }^{3} \mathrm{H}\right] \mathrm{NMS}$ and autoradiography $(c)$, a section of $\mathrm{P} 4$ rat footpad from another animal shown in dark-field demonstrates that cells in this region already express detectable levels of muscarinic binding sites. $d$, Many brightly immunofluorescent nuclei are evident in the presumptive secretory tubules (arrows) following a $2 \mathrm{hr}$ pulse with BrdU, a thymidine analog that is incorporated into DNA during S-phase and can be localized with a monoclonal antibody. Such labeling indicates a high level of mitotic activity in the forming glands. In situ hybridization autoradiograms were exposed for 6 weeks; receptor autoradiograms were exposed for 12 weeks. Magnification: $a$ and $b, 315 \times ; c, 450 \times ; d, 220 \times$.
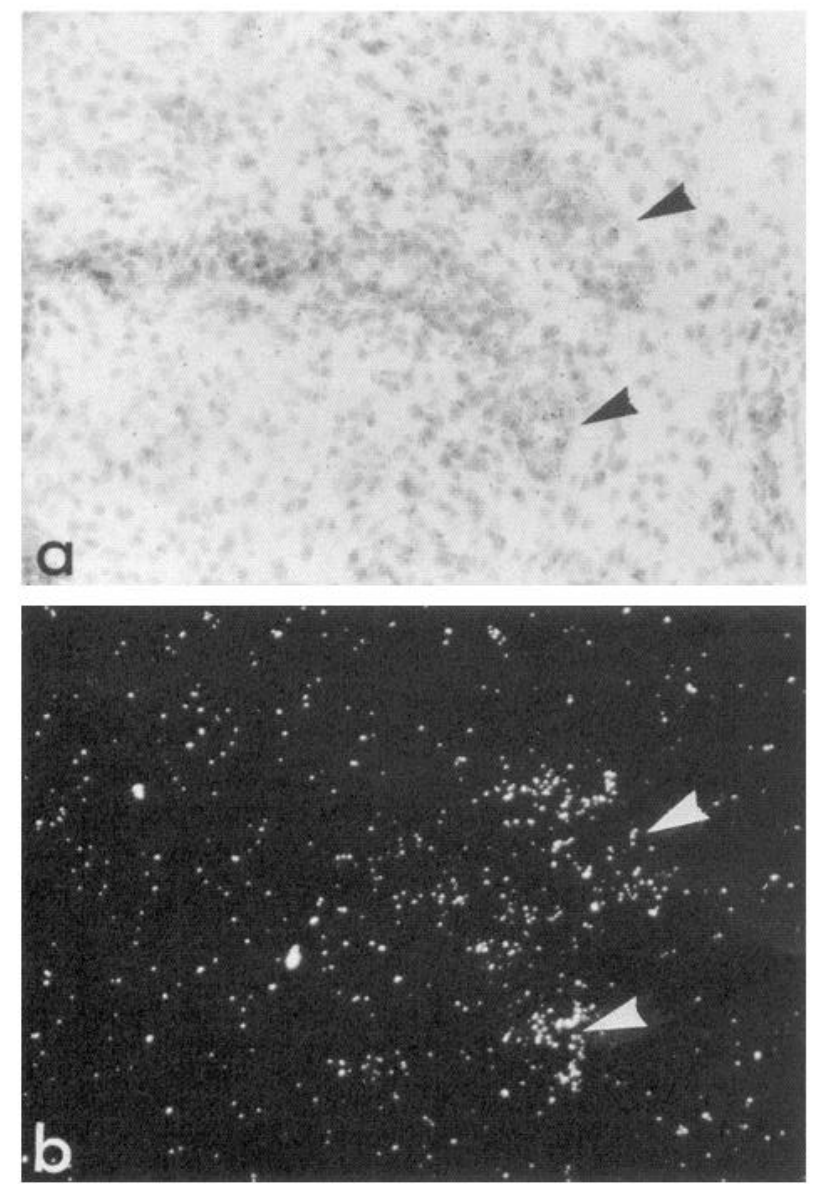

formate $/ 5$ mm sodium tetraborate. Total ${ }^{3} \mathrm{H}$-inositol phosphates were eluted with a $0.1 \mathrm{M}$ formic acid/ $0.2 \mathrm{M}$ ammonium formate solution, Formula 963 scintillation fluid was added, and the vials were counted. The total amount of ${ }^{3} \mathrm{H}$-labeled lipids was similar in each trial and was assayed by counting a small aliquot of the organic phase during the extraction procedure; however, the data were standardized to total protein. Protein concentration was determined by the method of Lowry et al. (1951).

\section{Results}

\section{Normal development of muscarinic receptors}

Both mRNA for the $m 3$ receptor and muscarinic ligand binding sites appear early in the development of sweat glands. In situ hybridization demonstrated that mRNA encoding the $\mathrm{m} 3$ receptor, the molecular subtype expressed by mature sweat glands (Grant et al., 1991), is present on P4 (Fig. 1a,b). At this age, the density of grains was approximately $32 \%$ of that present in normal adult glands. Specific muscarinic binding sites were also detectable in autoradiographic studies of P4 glands; the density was $18 \%$ of the normal adult density (Fig. $1 c$ ). When P4 rat pups were injected with $\mathrm{BrdU}$, a thymidine analog that is incorporated in the DNA of rapidly dividing cells, and footpad tissue taken for the immunocytochemical localization of BrdU $2 \mathrm{hr}$ later, many nuclei of the cells that form the presumptive secretory tubule were brightly fluorescent (Fig. 1d). These results indicate that muscarinic ligand binding sites are present early

\section{$\leftarrow$}

Figure 2. Gradient of $\mathrm{m} 3 \mathrm{mRNA}$ expression in a developing secretory tubule at P7. An epidermal invagination is shown in bright-field $(a)$. Dark-field examination $(b)$ of the presumptive secretory tubule demonstrates a higher level of $\mathrm{m} 3 \mathrm{mRNA}$ expression in the distal portion (arrowheads) of the invagination. In situ hybridization autoradiograms were exposed for 6 weeks. Magnification, 157×. 

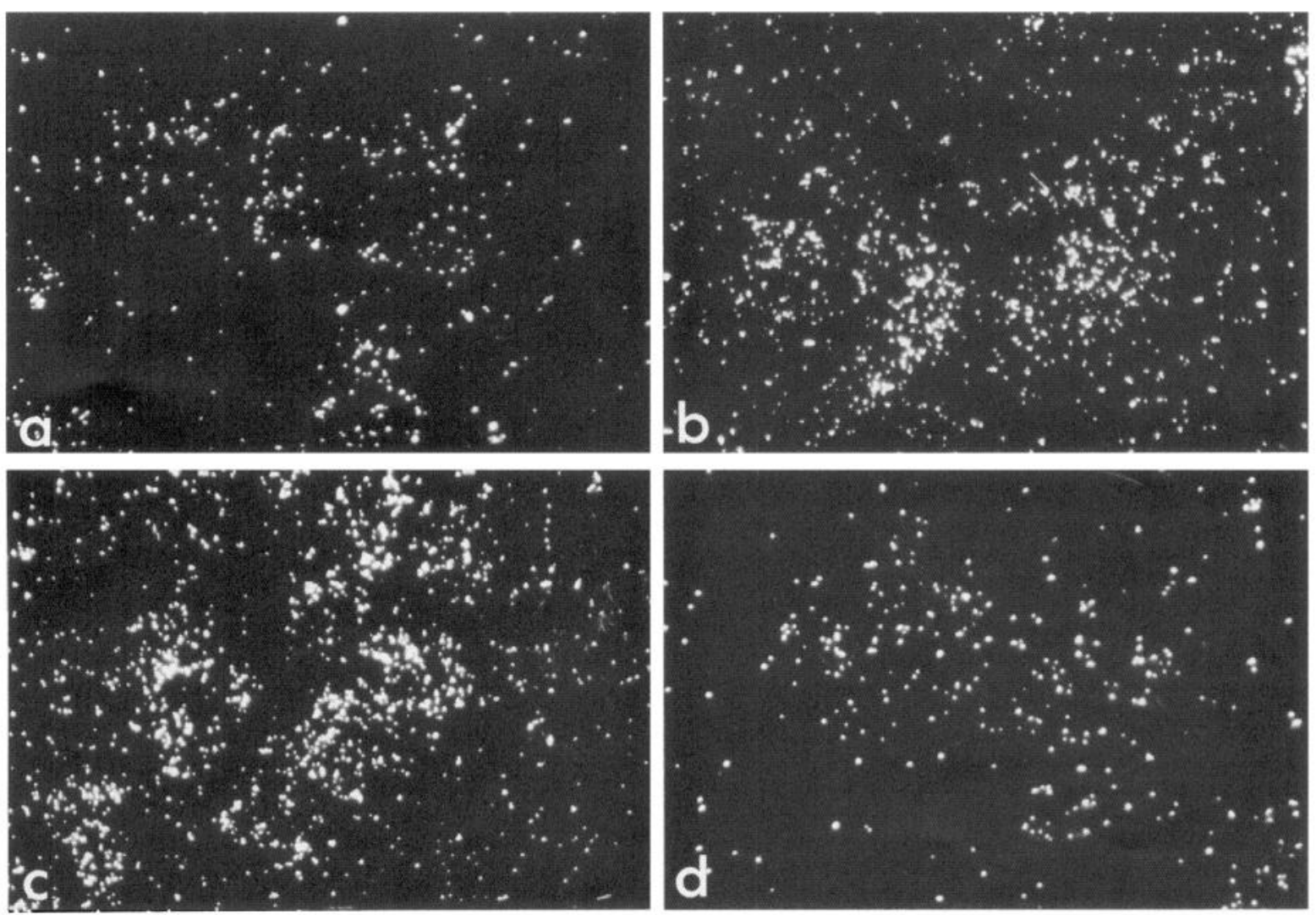

Figure 3. Development of $\mathrm{m} 3 \mathrm{mRNA}$ in rat sweat glands. Ten-micron sections of developing rat footpad were hybridized with an ${ }^{35} \mathrm{~S}$-labeled $\mathrm{m} 3$ receptor subtype-specific oligonucleotide probe. Examination of the autoradiograms under dark-field revealed a low level of expression of m3 mRNA on P7 (a), followed by a sharp increase in expression on P10 $(b)$ and P14 $(c)$ to adult levels $(d)$. Messages for the other molecular subtypes were not detectable. In situ hybridization autoradiograms were exposed for 6 weeks. Magnification, $315 \times$.

in the development of the sweat glands, $10 \mathrm{~d}$ before differentiated secretory cells and myoepithelial cells can be identified by morphological criteria, and they suggest that mitotically active gland precursor cells possess muscarinic receptors. Furthermore, although sympathetic axons are associated with the developing glands at this age, the terminals contain catecholamines; specific activity for ChAT, the synthetic enzyme for $\mathrm{ACh}$, is not detectable for another week (Landis and Keefe, 1983; Leblanc and Landis, 1986). Thus, muscarinic receptors are expressed by the presumptive target cells well before the developing innervation acquires a cholinergic phenotype.

During the second postnatal week the concentration of mRNA encoding the $m 3$ receptor increased significantly, reaching adult levels by P10. The density of grains corresponding to the level of $\mathrm{m} 3 \mathrm{mRNA}$ was approximately the same at P7 as on P4 (41\% and $32 \%$ of normal adult levels, respectively). Longitudinal sections through the developing glands of $\mathrm{P} 7$ pups revealed a higher level of $\mathrm{m} 3 \mathrm{mRNA}$ expression in the distal portion of the invagination than in the more proximal region (Fig. 2). The level of mRNA was increased significantly on P10 to $114 \%$ of adult levels, and this level of expression was maintained to adulthood (Figs. 3, 4). Thus, comparatively high levels of $m 3$ mRNA are present during the major period of gland morphogenesis, and message level is maintained after the acquisition of cholinergic function by the innervation and the onset of the physiological function of the sweat glands.

Autoradiographic examination of the development of muscarinic binding sites disclosed a fivefold increase in the density of [ $\left.{ }^{3} \mathrm{H}\right]$ NMS binding sites between P4 and P14; the density on P14 was not significantly different from adult levels (Figs. 5, 6). A significant concentration of muscarinic ligand binding sites was evident at P4. Between P7 and P14, the density of binding sites rose rapidly from $37 \%$ to $108 \%$ of control adult density. After P14, a small but not significant decrease to the normal adult concentration was observed. These data suggest that most sweat glands have acquired the adult concentration of muscarinic ligand binding sites at an age when only a small proportion of glands sweat in response to nerve stimulation and muscarinic agonists (Stevens and Landis, 1987).

\section{Development of muscarinic receptors in the absence of innervation}

To investigate a possible relationship between the expression of muscarinic receptors and the development of gland innervation, we determined the concentration and $K_{d}$ of muscarinic receptors in homogenates of gland-rich tissue isolated from adult animals that were chemically sympathectomized as neonates by treatment with 6-OHDA (Fig. 7). Sweat glands in 6-OHDAtreated rats develop in the absence of autonomic innervation and do not secrete in response to either nerve stimulation or the injection of muscarinic agonists (Yodlowski et al., 1984; Stevens and Landis, 1987). Scatchard analysis was performed on binding data obtained with homogenates of gland-rich tissue incubated with increasing concentrations of $\left[{ }^{3} \mathrm{H}\right] \mathrm{NMS}$. Although there appeared to be a reduction in the concentration of muscarinic ligand binding sites, $238.0 \mathrm{fmol} / \mathrm{mg}$ membrane protein 


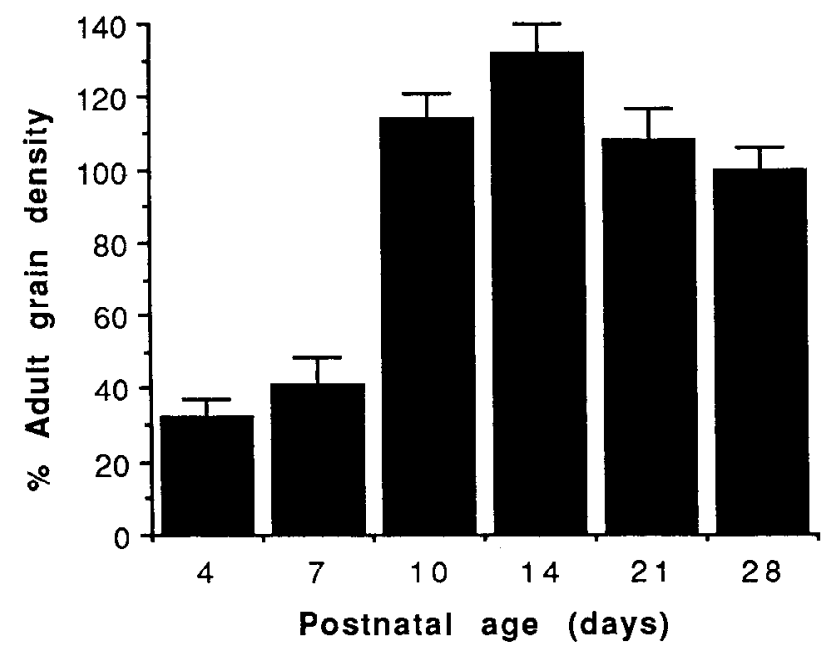

Figure 4. Quantitative analysis of $\mathrm{m} 3 \mathrm{mRNA}$ expression. Autoradiograms were exposed for 6 weeks, the specific grain density was determined with an Olympus Cue-4 image analysis system, and the density is here expressed as a percentage of the adult grain density ( $>6$ weeks postnatal). Each bar represents the analysis of at least 25 fields \pm SEM. The increase between P7 and P10 is statistically significant $(p<0.05)$; the levels do not change significantly thereafter.

in the experimental as compared to $301.0 \mathrm{fmol} / \mathrm{mg}$ in the control, the reduction was not significant $(p>0.05)$. The $K_{d}$ was unchanged, $156 \mathrm{pm}$ in the experimental as compared to $131 \mathrm{pM}$ in the control.

Examination of light microscopic autoradiograms of footpad sections did not disclose an obvious difference in the number or distribution of muscarinic binding sites when control and uninnervated glands were compared (Fig. 8a,b). Quantitative analysis of the autoradiograms revealed that the density of grains over uninnervated glands was $92 \%$ of the grain density over control adult glands. Thus, the appearance of high concentrations of muscarinic ligand binding sites in sweat glands is not dependent upon the presence of sympathetic innervation. Although neither ligand binding nor autoradiography revealed a significant difference, the ratio of binding site density (uninnervated: normal) determined in homogenate binding studies was lower than that determined by autoradiography (homogenate, 0.79; autoradiography, 0.92). This discrepancy may be due to the fact that sweat glands are smaller in sympathectomized rats; when binding sites are normalized on a per milligram protein basis, the relative amount of sweat gland per mass of tissue may be less in the uninnervated animals and result in a lower estimate of binding site density.

Competition studies were performed with selective muscarinic antagonists and in situ hybridization studies were undertaken with receptor subtype-specific probes to determine whether the muscarinic receptor subtype expressed by uninnervated glands differed from that expressed in normal glands. Pirenzepine identified a single site in homogenates of gland-rich tissue isolated from 6-OHDA-treated animals, having a $K_{i}$ of 0.313 $\mu \mathrm{M}$, which is consistent with values obtained for normal glands (Fig. 9). The $\mathrm{M}_{2}$ glandular-selective ligand 4-DAMP recognized a single class of high-affinity sites with a $K_{i}$ of $0.032 \mu \mathrm{M}$, similar to control. AF DX-116, the $\mathrm{M}_{2}$ heart-selective ligand, recognized a single class of low-affinity sites with a $K_{i}$ of $1.8 \mu \mathrm{M}$. In situ hybridization demonstrated that sympathectomized glands express the $\mathrm{m} 3$ molecular receptor subtype (Fig. $8 c, d$ ), the re- ceptor subtype present in normal adult glands (Grant et al., 1991). The level of mRNA in sympathectomized glands was not significantly different from control $(p>0.05)$. No message for other muscarinic receptor subtypes was detected. These data suggest that uninnervated sweat glands do not express a different receptor subtype than normal innervated glands.

To determine whether the muscarinic receptors were functionally coupled to their intracellular second messenger system, slices of footpad isolated from control, sympathectomized, and acutely denervated animals were assayed for muscarinic receptor-mediated PI turnover. Previous studies have shown that the $\mathrm{m} 3$ muscarinic receptor subtype is expressed in other secretory glands and that the $\mathrm{m} 3$ receptor preferentially interacts with phospholipase C (Akiba et al., 1988; Bonner et al., 1988; Peralta et al., 1988). Additionally, secretory function in lacrimal cells appears to be regulated by way of the PI pathway (Trautman and Marty, 1984; Evans and Marty 1986a,b; reviewed by Marty, 1987). Thus, by examining alterations in PI turnover in response to muscarinic agonists, we could assay the proximal portion of the second messenger pathway believed to be involved in secretion. Incubation of adult rat footpad slices with $100 \mu \mathrm{M}$ carbachol resulted in approximately a fourfold increase in the accumulation of total ${ }^{3} \mathrm{H}$-inositol phosphates (Fig. 10), which was abolished by the inclusion of $10 \mu \mathrm{M}$ atropine in the incubation buffer. Since local injections of VIP, a neuropeptide present in the sweat gland innervation (Yodlowski et al., 1984; Landis and Fredieu, 1986), stimulate secretion from rat sweat glands (Stevens and Landis, 1987), we also assayed its effects on PI turnover. Incubation of adult rat footpad slices with $10 \mu \mathrm{M}$ VIP did not produce a detectable change in inositol phosphate metabolism (data not shown), consistent with the observation that VIP-stimulated secretion is blocked by atropine and does not appear to be a direct effect on gland cells (Stevens and Landis, 1987). Muscarinic cholinergic receptors expressed by sweat glands of sympathectomized animals are also functionally coupled to PI metabolism. Incubation of footpad slices isolated from sympathectomized rats with $100 \mu \mathrm{M}$ cabachol resulted in a fourfold increase in the total accumulation of PIs, which was atropine sensitive (Fig. 10). Similar results were obtained with slices of acutely denervated rat footpad. In both cases, the levels of total ${ }^{3} \mathrm{H}$-PI accumulation were identical to those in slices from control animals.

\section{Discussion}

To characterize developmental interactions between sympathetic neurons and their target tissues further, we have analyzed the development of muscarinic receptors in rat sweat glands and examined the effects of sympathectomy on their expression and coupling to PI turnover. One of the first signs of differentiation of the presumptive gland cells is the appearance of $\mathrm{m} 3$ message and muscarinic binding sites on $\mathrm{P} 4$, when division is actively occurring. During the second postnatal week, the levels of mRNA encoding the $\mathrm{m} 3$ receptor and of muscarinic binding sites increased rapidly and reached levels that were maintained to adulthood. Development of sweat glands in the absence of sympathetic innervation leads to nonresponsive sweat glands in the adult (Stevens and Landis, 1987); it does not, however, change the concentration or distribution of muscarinic receptors, nor does it alter the molecular subtype expressed by the gland. Stimulation of muscarinic receptors of normal adult glands increases PI turnover. Similarly, glands that are nonresponsive due to development in the absence of sympathetic innervation or to 

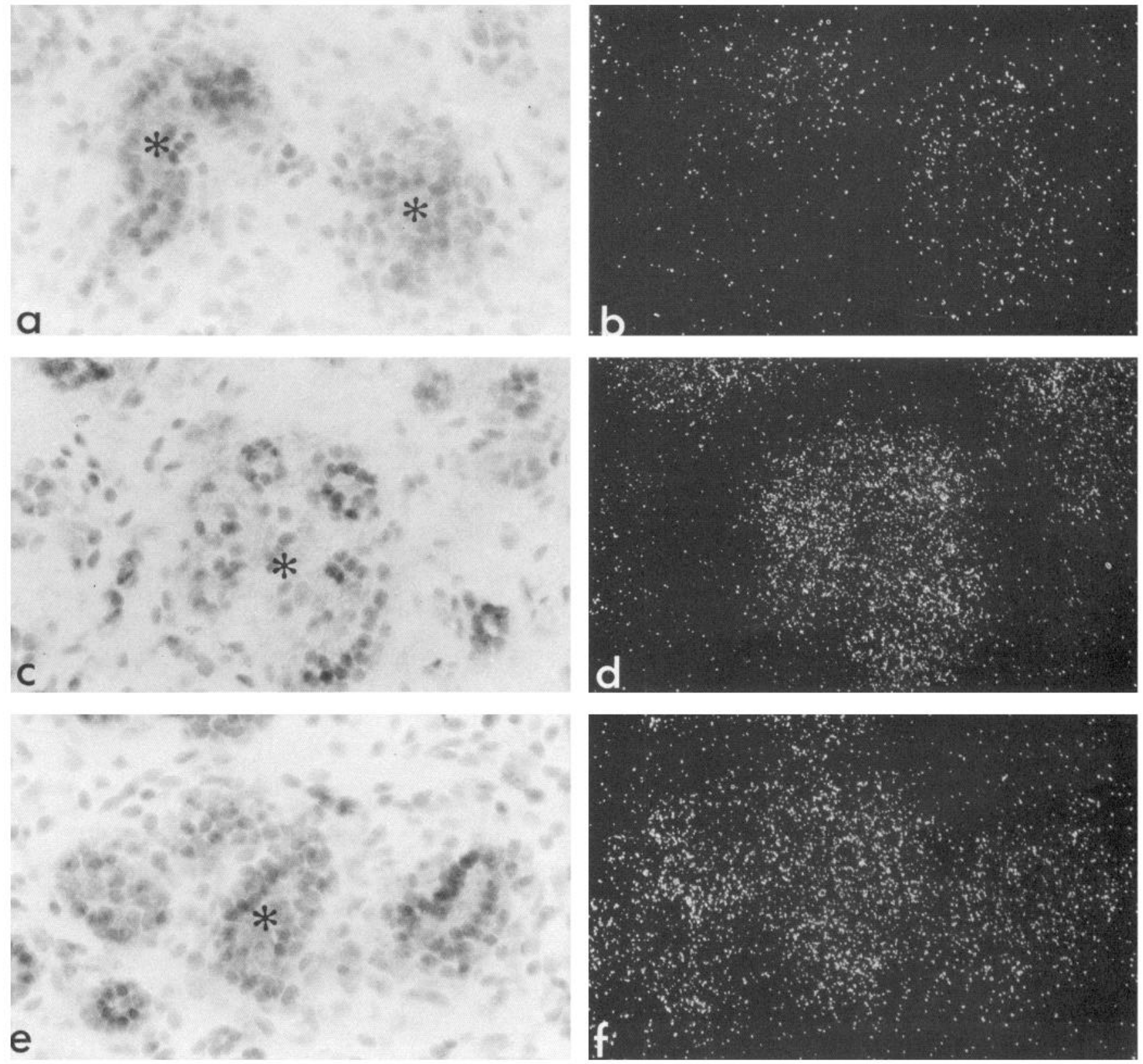

Figure 5. Development of muscarinic ligand binding sites in footpads of postnatal rats. Ten-micron sections of rat footpad were incubated with $1 \mathrm{nM}\left[{ }^{3} \mathrm{H}\right] \mathrm{NMS}$, and the sections were processed for autoradiography. Bright-field $(a, c, e)$ and corresponding dark-field $(b, d, f)$ views of developing rat sweat glands are shown. (Asterisks indicate sweat glands.) The number of binding sites increased by P7 $(a, b)$, and by P14 the density of sites $(c, d)$ approached the concentration observed on P28 $(e, f)$. Receptor autoradiograms were exposed for 12 weeks. Magnification, $450 \times$.

acute denervation after section of the sciatic nerve exhibited normal levels of muscarinic-mediated PI turnover.

When muscarinic receptors are first detected on $\mathrm{P} 4$, catecholamine-containing sympathetic axons are just contacting the developing glands (Landis and Keefe, 1983), and many of the gland precursor cells derived from the epidermis are mitotically active. Although the early expression of muscarinic receptors in chick heart (Galper et al., 1977) and muscarinic and $\beta$-adrenergic receptors in rat parotid gland (Lunford and Talamo, $1980,1983)$ has been described previously, the relationship of expression to cessation of cell division and differentiation has not been defined. Receptor expression, in fact, appears to be one of the first signs of overt differentiation of secretory tubule cells. Thus, the early appearance of muscarinic receptors in the developing glands suggests that their initial expression is part of an intrinsic program of differentiation of the secretory tubule that is triggered by interactions between the epidermis and dermis. Differentiation alone has been suggested to regulate the expression of $\beta_{1}$ - and $\beta_{2}$-adrenergic receptor mRNA and protein in 3T3-L1 cells, a cell line that exhibits a fibroblast-like phenotype and can acquire an adipocyte-like phenotype (Guest et al., 1990). Conversely, both soluble factors and cell-cell interactions have been shown to influence the expression of muscarinic and $\beta$-adrenergic receptors in vitro (Harden et al., 1979; Smith and Kessler, 1988; reviewed in Grant and Landis, 1991). It is not known, however, whether these mechanisms play a role 


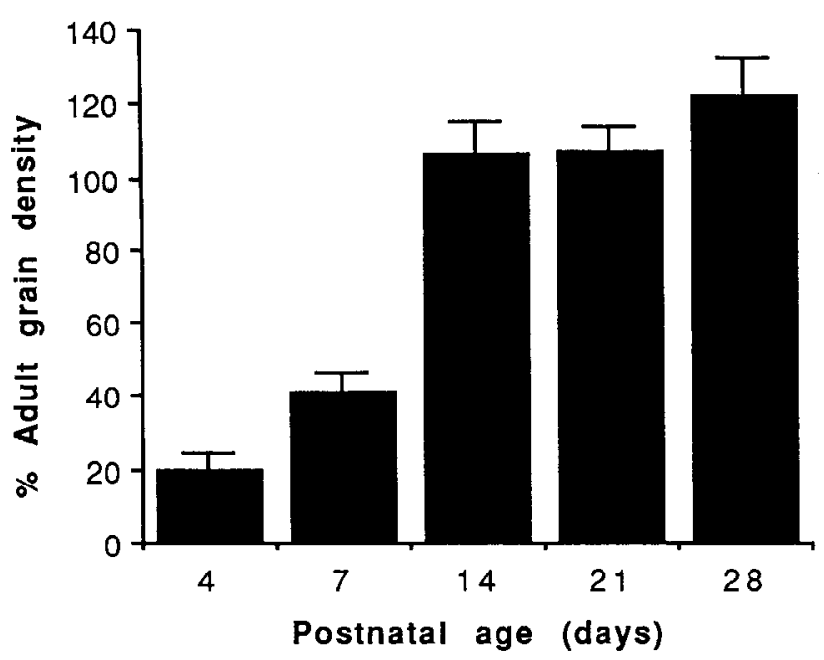

Figure 6. Quantitative analysis of the development of muscarinic binding sites. Three sets of sections, each representing the several postnatal ages, were processed for autoradiography. The sections were exposed for 13 weeks and developed together. The specific grain density was determined with an Olympus Cue-4 image analysis system, and the density is here expressed as a percentage of the adult grain density ( $>6$ weeks postnatal). Each $b a r$ represents the analysis of at least 25 fields \pm SEM. The increasc betwecn P7 and P14 is statistically significant $(p$ $<0.05$ ); the levels do not change significantly thereafter.

in regulating the initial expression of muscarinic receptors in vivo.

Our studies have shown there is a close correlation between the level of $\mathrm{m} 3 \mathrm{mRNA}$ expression and the density of muscarinic binding sites throughout development. During the first postnatal week, $\mathrm{m} 3$ receptor message and muscarinic ligand binding sites are expressed at low levels in sweat glands; their levels rise significantly and reach adult levels during the second postnatal week. Guest and colleagues have reported a similar correlation in the expression of $\beta_{1}$ - and $\beta_{2}$-adrenergic receptor mRNA and the density of $\beta_{1}$ - and $\beta_{2}$-adrenergic receptor binding sites during the differentiation of 3T3-L1 cells (Guest et al., 1990).

When the developmental time course of muscarinic receptor expression is compared with that of ChAT activity, it is clear that receptor expression precedes the appearance of cholinergic function in the innervation. ChAT activity is not detectable until $\mathrm{P} 11$, is less than $20 \%$ of adult levels on P14, and continues to increase over the next several weeks (Leblanc and Landis, 1986), while muscarinic receptors have already attained their adult concentration by P14. The pattern of muscarinic receptor development in sweat glands and its temporal relationship to the developing innervation appear to differ from those described for two other peripheral autonomic targets, chick heart and rat parotid gland. In the chick, vagal fibers reach the developing heart on days 4-5 in ovo, and parasympathetic synaptic transmission is established shortly thereafter. At embryonic day 4 (E4) the concentration of muscarinic receptors is already 165 $\mathrm{fmol} / \mathrm{mg}$ protein, and their concentration does not change significantly with further development. In the rat parotid gland, muscarinic receptors first appear on $\mathrm{P} 2$, and their concentration rises to adult levels by P25 (Lunford and Talamo, 1980). Cholinergic innervation of parotid gland, assayed by the appearance of ChAT activity, occurs with a similar time course; it is initially detected early in the first postnatal week, and adult levels are achieved by the middle of the fourth postnatal week. Thus,

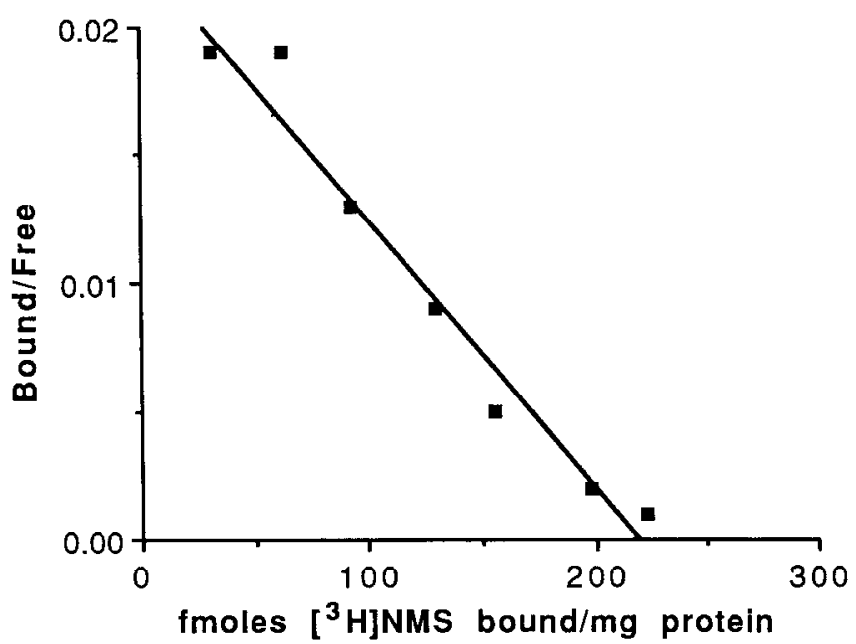

Figure 7. Equilibrium binding of $\left[{ }^{3} \mathrm{H}\right] \mathrm{NMS}$ to homogenates of rat footpad isolated from adult animals chemically sympathectomized as neonates. Homogenates of footpads from rats treated with 6-OHDA as neonates were incubated with increasing concentrations of $\left[{ }^{3} \mathrm{H}\right] \mathrm{NMS}$ $(0.025-1.25 \mathrm{~nm})$, and the binding data were analyzed by the Scatchard method. The data shown are representative of results obtained in four separate experiments. Each point is the mean of three determinations. The calculated $K_{d}$ and $B_{\max }$ for this experiment were $162 \pm 8 \mathrm{pM}$ and $227 \pm 21 \mathrm{fmol} / \mathrm{mg}$ protein, respectively. Following EBDA/LIGAND analysis, the $K_{\alpha}$ of the receptor was determined to be $156 \pm 10 \mathrm{pM}$, and the $B_{\max }, 238 \pm 26 \mathrm{fmol} / \mathrm{mg}$ protein $(n=4)$. Ncither the $K_{d}$ nor the $B_{\max }$ was significantly different from control $\left(K_{d}, 131 \pm 6\right.$ pM; $B_{\max }, 301 \pm$ $24 \mathrm{fmol} / \mathrm{mg}$ protein; $n=5 ; p>0.05)$.

muscarinic receptors are present to varying degrees in autonomic targets prior to cholinergic innervation, and there does not appear to be a simple relationship between the level of receptor expression and developmental changes in cholinergic function exhibited by the innervation.

Identification of the molecular diversity of muscarinic receptors has led to the suggestion that one or more of the molecular subtypes may be a developmental specialization (Bonner, 1989), analogous to the expression of the $\gamma$-subunit of the nicotinic ACh receptor in developing skeletal muscle and its replacement by $\epsilon$-subunit in normal adult muscle (Mishina et al., 1986; Moss et al., 1987). Muscarinic receptors constitute a gene family of five molecular subtypes (Kubo, 1986a,b; Bonner et al., 1987, 1988; Peralta et al., 1987a,b; Akiba et al., 1988), with different functional properties (Bonner et al., 1988; Fukuda et al., 1988; Jones et al., 1988; Peralta et al., 1988) and tissue distributions (Buckley et al., 1988; Maeda et al., 1988). Analyses of the development of the several molecular subtypes have not been performed, but pharmacological studies have raised the possibility that receptor subtypes may be regulated differently during development. For example, in rat cortex, the proportion of $\mathbf{M}_{1}$ and $M_{2}$ receptors defined by pirenzepine binding experiments is equal at the end of the first postnatal week, but the concentration of $M_{1}$ receptors increases threefold over the following three weeks while the concentration of $\mathbf{M}_{2}$ receptors remains unchanged (Lee et al., 1990). While these findings are consistent with developmental regulation, the relationship between celltype and receptor-subtype expression in the developing cortex has not been explored, and the changes observed need not occur in the same cells. In the present studies of developing sweat glands, wc detected the expression of only $\mathrm{m} 3$ receptor message. Thus, the muscarinic cholinergic receptors expressed in this 

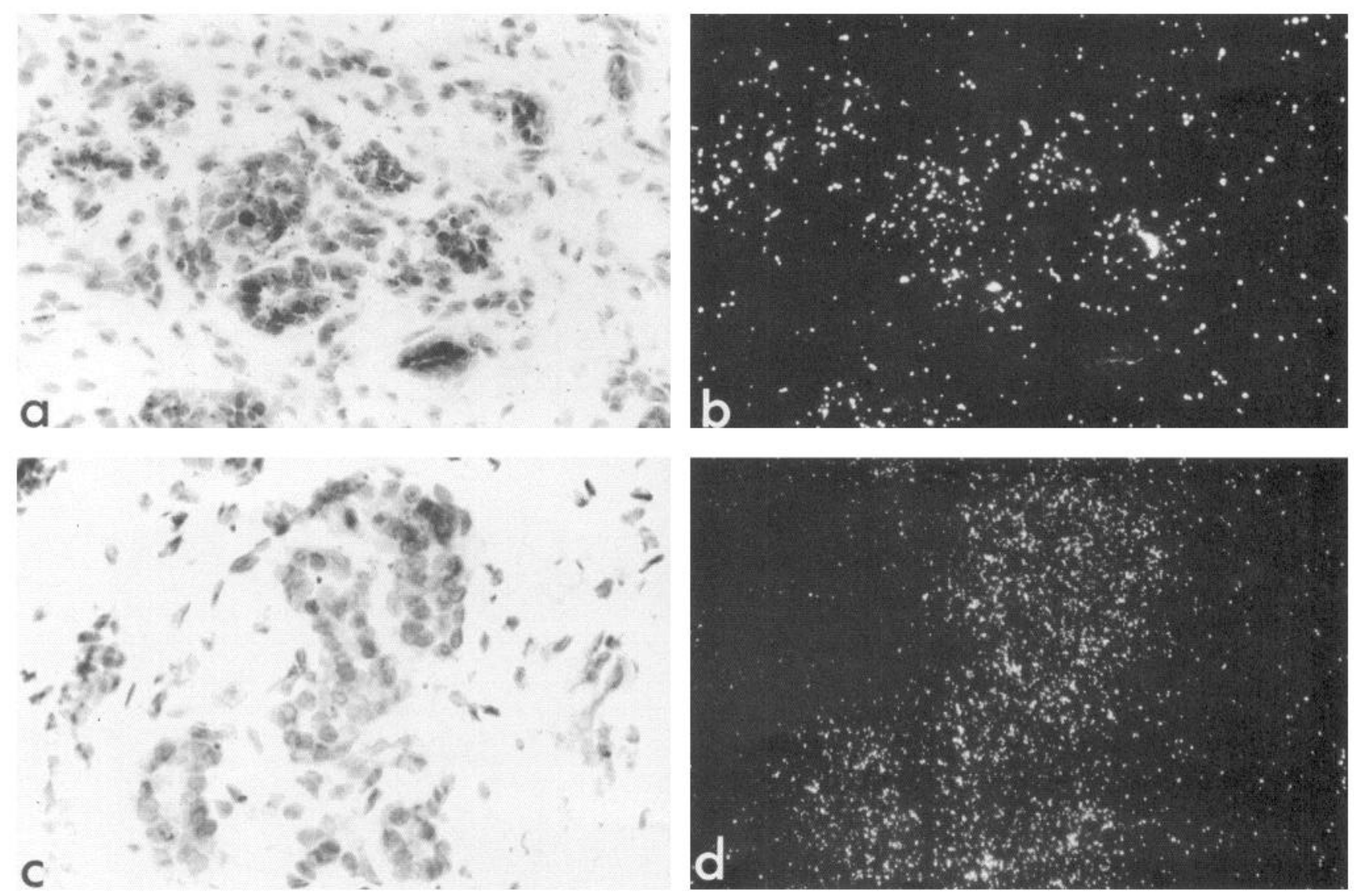

Figure 8. Autoradiograms of $\left[{ }^{3} \mathrm{H}\right] \mathrm{NMS}$ binding and in situ hybridization with an ${ }^{35} \mathrm{~S}$-labeled $\mathrm{m} 3$ receptor subtype-specific oligonucleotide probe to sections of footpads from adult rats chemically sympathectomized at birth by treatment with 6-OHDA. Ten-micron sections were incubated with $1 \mathrm{nM}\left[{ }^{3} \mathrm{H}\right] \mathrm{NMS}$ or hybridized with an m3-specific oligonucleotide probe and processed for autoradiography. Secretory coils are shown in bright-field $(a, c)$. Dark-field micrographs reveal a high concentration of grains over the secretory coils corresponding to $\left[{ }^{3} \mathrm{H}\right] \mathrm{NMS}$ binding sites $(b)$ and $\mathrm{m} 3$ mRNA $(d)$. The density of specific grains was not significantly different for receptor autoradiography (92 $\pm 9 \%$ of control) or in situ hybridization $(90 \pm 11 \%$ of control). Receptor autoradiograms were exposed for 12 weeks, and in situ hybridization autoradiograms were exposed for 6 weeks. Magnification, $315 \times$.

autonomic target tissue, at least, consist of a single molecular subtype that appears unchanged throughout development.

The normal pattern of innervation during development is not required to achieve the characteristic adult complement of receptors. In rats treated with 6-OHDA at birth, sweat glands that were never innervated by sympathetic axons express the same receptor subtype defined by pharmacological and molecular criteria. Furthermore, the concentration and affinity were also not significantly different from control, nor was the distribution of ligand binding sites analyzed at the light microscopic level. Although the glands in 6-OHDA-treated rats are not innervated by sympathetic axons, they are invested by sensory axons that contain substance $P$ and CGRP (Yodlowski et al., 1984; Landis and Fredieu, 1986). We cannot exclude the possibility that the abnormal sensory innervation influences muscarinic receptor expression. While neither noradrenergic nor cholinergic sympathetic innervation is required for the acquisition of muscarinic binding sites, however, cholinergic innervation is necessary to establish secretory function in the glands (Stevens and Landis, 1987).

In the present study we have found that essentialiy normal levels of muscarinic binding sites in sweat glands are expressed in the absence of secretory responsiveness under two conditions: in glands of P14 rats during normal development and in glands of adult rats that developed in the absence of sympathetic cholinergic innervation. Additionally, we have demonstrated that denervation of adult sweat glands does not alter the concentration of muscarinic binding sites but causes loss of secretory function (Grant et al., 1991). In the case of ligand-gated ion channels, expression of the receptor/channel complex is thought under most conditions to be sufficient to produce a functional response upon ligand binding (for an exception, see Margiotta et al., 1987; reviewed by Berg et al., 1989). In contrast to ligandgated ion channels, however, responses due to activation of G-protein-coupled receptors depend on several postreceptor proteins. Thus, a secretory response to muscarinic stimulation in sweat glands requires not only the receptor, but also an intact second messenger cascade and appropriate effector proteins.

The molecular mechanisms that subserve secretion in rat sweat glands are incompletely understood. It has been established that the secretory effluent of rat sweat glands is a high-potassium and low-sodium fluid, and that secretion is calcium dependent (Sato and Sato, 1978). Studies of other exocrine glands in which secretion is likely to be analogous to that of sweat glands, primarily parotid and lacrimal glands, provide insight into the molecular mechanisms that control fluid secretion from exo- 


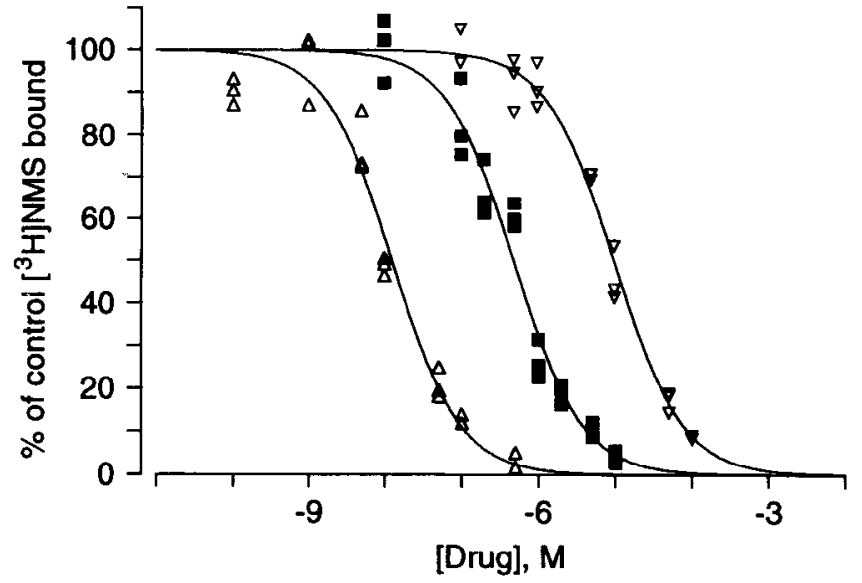

Figure 9. Inhibition of $\left[{ }^{3} \mathrm{H}\right] \mathrm{NMS}$ binding by three subtype-selective antagonists, 4-DAMP (triangles), pirenzepine (squares), and AF DX116 (inverted triangles), to homogenates of rat footpads isolated from adult animals chemically sympathectomized as neonates. The data shown are representative of results obtained in two to five separate experiments; for each concentration of competing ligand, the triplicate data points are plotted. The $\mathrm{IC}_{50}$ values for these experiments were 4-DAMP, 0.012 $\mu \mathrm{M}$; pirenzepine, $0.490 \mu \mathrm{M}$; and AF DX-1 16,9.9 $\mu \mathrm{M}$. Competition curves were analyzed with the EBDA/LIGAND program, and the $K_{i}$ values were determined. The calculated $K_{i}$ values were 4-DAMP, $0.020 \mu \mathrm{M}$; pirenzepine, $0.244 \mu \mathrm{M}$; and AF DX-116, $1.12 \mu \mathrm{M}$.

crine glands. In slices of parotid gland, muscarinic stimulation leads to a large efflux of $\mathrm{K}^{+}$, which is dependent on the release of $\mathrm{Ca}^{2+}$ from an unidentified receptor-regulated intracellular pool (Haddas et al., 1979; Aub et al., 1982; Poggioli and Putney, 1982). Single-channel analysis of cells isolated from mouse lacrimal glands has established that $\mathrm{Ca}^{2+}$ activates a large potassium channel, the BK channel, and a chloride channel (Trautman and Marty, 1984; Evans and Marty, 1986a,b). Dialysis of the cells with $\mathrm{GTP} \gamma \mathrm{S}$ or inositol triphosphate $\left(\mathrm{IP}_{3}\right)$ produces similar currents. These observations suggest that G-proteinmediated hydrolysis of membrane phospholipids that leads to the production of $\mathrm{IP}_{3}$ is responsible for the generation of the intracellular calcium transient (Evans and Marty, 1986b). These data, taken together, suggest that exocrine secretion results from muscarinic stimulation of phospholipid hydrolysis and the production of $\mathrm{IP}_{3}$, which stimulates the release of calcium to cause the activation of potassium and chloride currents. Interestingly, cell transfection studies have shown that the $\mathrm{m} 3$ molecular subtype, which is expressed in sweat glands, is coupled to phospholipase $\mathrm{C}$ and that activation of this receptor stimulates the release of intracellular calcium (Neher et al., 1988; Peralta et al., 1988; Lechleiter et al., 1989). These observations on the properties of the $m 3$ receptor and its presence in sweat glands are consistent with the mechanism of sweat secretion deduced from parotid and lacrimal glands.

To define more clearly the point at which signal transduction in response to muscarinic agonists is blocked in nonresponsive sweat glands, we have determined whether the receptors are coupled to their postulated second messenger system, stimulation of membrane phospholipid hydrolysis. We found that treatment of slices of gland-rich tissue isolated from control rats with a cholinergic agonist produced a fourfold increase in the concentration of total ${ }^{3} \mathrm{H}$-inositol phosphates. Similarly, stimulation of slices isolated from rats sympathectomized at birth as well as from rats denervated for a period of $7 \mathrm{~d}$ produced a

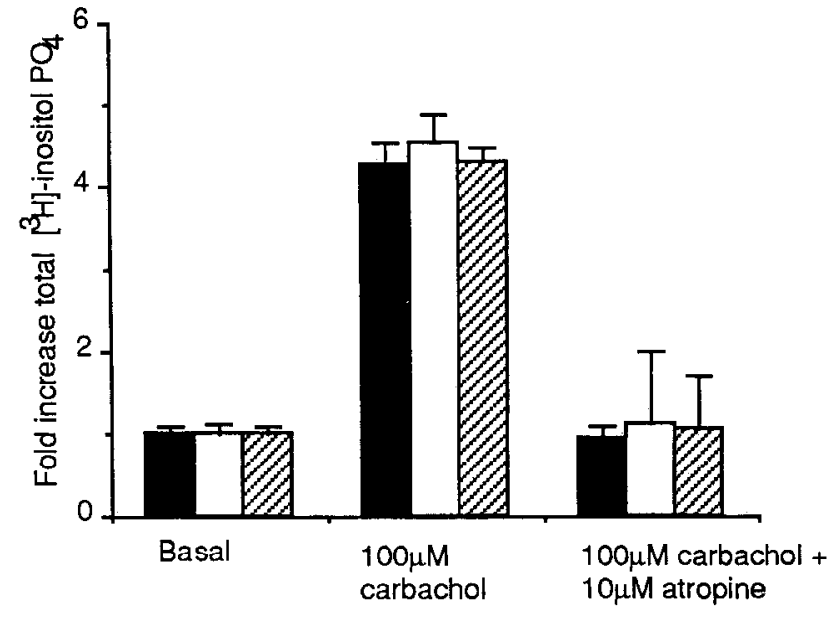

Figure 10. Stimulation of PI turnover in slices of control and experimental footpads. Slices of gland-rich tissue isolated from control (solid bars), 6-OHDA (open bars), and denervated (cross-hatched bars) animals were incubated for $1 \mathrm{hr}$ under the following conditions: incubation buffer (basal), $100 \mu \mathrm{M}$ carbachol, and $100 \mu \mathrm{M}$ carbachol plus $10 \mu \mathrm{M}$ atropine; the total ${ }^{3} \mathrm{H}$-inositol phosphates were then determined. Carbachol produced a fourfold increase in the amount of total ${ }^{3} \mathrm{H}$-inositol phosphates generated, and atropine abolished the increase. Carbachol also produced approximately a fourfold increase in the amount of total ${ }^{3} \mathrm{H}$-inositol phosphates in slices of footpad isolated from denervated and 6-OHDA-treated animals. Each bar represents the mean of three experiments \pm SEM.

fourfold increase in the concentration of total inositol phosphates. These data indicate that the muscarinic receptors expressed on nonresponsive glands are functionally coupled to phospholipase $\mathrm{C}$ and suggest that the proximal portion of the signal transduction pathway is intact in nonresponsive rat sweat glands. The possibility remains that while flux through the PI pathway as a whole is not significantly different, the distribution of metabolites is altered such that active isomers are not generated in the nonresponsive glands (reviewed in Berridge and Irvine, 1989); however, preliminary results suggest that the levels of muscarinic-stimulated $\mathrm{IP}_{3}$ in control and sympathectomized sweat glands are not significantly different. A lack of cellular responsiveness to muscarinic cholinergic stimulation has also been observed in the presence of the appropriate G-protein in embryonic chick heart (Hunter and Nathanson, 1984, 1986). When newly synthesized muscarinic receptors are examined in this system, initially they are poorly coupled to the inhibition of adenyl cyclase and muscarinic ACh receptor-stimulated increase in $\mathrm{K}^{+}$permeability despite the presence of G-proteins. Thus, the response of a cell to muscarinic stimulation can be regulated at the level of the G-protein or distal to the receptor/G-protein interaction. While the muscarinic receptors expressed by denervated and sympathectomized rat sweat glands are functionally coupled to PI turnover, it is not clear if the normal development of physiological responsiveness is regulated at a similar point in the signal transduction pathway. In chick heart, the development of muscarinic-mediated regulation of cAMP concentration is correlated with the appearance of a pertussis toxin-sensitive G-protein (Halvorson and Nathanson, 1984; Liang et al., 1986).

Our results are consistent with the hypothesis that cholinergic innervation regulates neither receptor expression nor G-protein coupling, but rather one or possibly several steps distal to the 
phospholipase C-dependent hydrolysis of membrane phospholipids and production of $\mathrm{IP}_{3}$ that are required for secretory responsiveness. Precedents do not exist that identify a particular step in the signal transduction pathway distal to PI turnover as a likely candidate for regulation. Preliminary results using fura-2 imaging indicate that intracellular $\mathrm{Ca}^{2+}$ transients are generated in both control and denervated secretory cells. These data suggest the most likely target for regulation is a protein, or proteins, that regulates channel function, or the potassium and/or chloride channels themselves.

The tight correlation between the presence of cholinergic innervation and secretory responsiveness raises the question of what property of the inncrvation is responsible for regulating responsiveness. Treatment of normal developing and adult rats with the muscarinic antagonist atropine provides evidence that it is ACh itself (Grant and Landis, unpublished observations). Consistent with this, treatment of adult rats with pilocarpine, a muscarinic antagonist, immediately following sciatic nerve section and gland denervation prevents the loss of secretory responsiveness. Thus, the target-directed induction of cholinergic. function in the sweat gland innervation (Schotzinger and Landis, $1988,1990)$ has important consequences for gland function. In other systems, muscarinic receptors have also been shown to mediate effects not traditionally associated with classical neurotransmitters. For example, muscarinic agonists regulate DNA synthesis in developing astroglia, and muscarinic stimulation appears to be a mitogenic signal in Chinese hamster ovary cells transfected with cDNAs encoding the $\mathrm{m} 1$ and $\mathrm{m} 3$ muscarinic receptors, which activate phospholipase $\mathrm{C}$ and stimulate PI turnover (Ashkenazi et al., 1989a,b). Although the molecular bases of the interactions between neurotransmitters and targets have yet to be elucidated, it is clear that neurotransmitters, particularly $\mathrm{ACh}$, can regulate important developmental events.

\section{References}

Akiba I, Kubo T, Maeda A, Bujo H, Nakai J, Mishina M, Numa S (1988) Primary structure of porcine muscarinic acetylcholine receptor III and antagonist binding studies. FEBS Lett 235:257-261.

Ashkenazi A, Ramachandran J, Capon DJ (1989a) Acetylcholine analogue stimulates DNA synthesis in brain-derived cells via specific muscarinic receptor subtypes. Nature 340:146-150.

Ashkenazi A, Peralta EG, Winslow JW, Ramachandran J, Capon DJ (1989b) Functional divcrsity of muscarinic receptor subtypes in cellular signal transduction and growth. Trends Pharmacol Sci [suppl]10: 34-38.

Aub DL, McKinney JS, Putney JW (1982) Nature of the receptor regulated calcium pool in the rat parotid gland. J Physiol (Lond) 331: $557-565$.

Berg DK, Boyd RT, Halvorson SW, Higgins LS, Jacob MH, Margiotta JS (1989) Regulating the number and function of neuronal acetylcholine receptors. Trends Neurosci 12:16-20.

Berridge MJ, Irvine RF (1989) Inositol phosphates and cell signalling. Nature 341:197-206.

Berridge MJ, Downes CP, Hanley MR (1982) Lithium amplifies agonist-dependent phosphatidylinositol responses in brain and salivary glands. Biochem J 206:587-595.

Bonner TI (1989) The molecular basis of muscarinic receptor diversity. Trends Neurosci 12:148-152.

Bonner TI, Buckley NJ, Young A, Brann MR (1987) Identification of a family of muscarinic receptor genes. Science 237:527-532.

Bonner TI, Young AC, Brann MR, Buckley NJ (1988) Cloning and expression of the human and rat $\mathrm{m} 5$ muscarinic acetylcholine receptor genes. Neuron 1:403-410.

Brenner HR, Sakmann B (1983) Neurotropic control of channel properties at neuromuscular synapses of rat muscle. J Physiol (Lond) 337: 159-174.
Buckley NJ, Bonner TI, Brann MR (1988) Localization of a family of muscarinic receptor mRNAs in rat brain. J Neurosci 8:4646-4652.

Evans MG, Marty A (1986a) Calcium-dependent chloride currents in isolated cells from rat lacrimal glands. J Physiol (Lond) 378:437-460.

Evans MG, Marty A (1986b) Potentiation of muscarinic and alphaadrenergic responses by an analogue of guanosine 5 'triphosphate. Proc Natl Acad Sci USA 83:4099-4103.

Fukuda K, Higashida H, Kubo T, Maeda A, Akiba I, Bujo H, Mishina M, Numa S (1988) Selective coupling with $\mathrm{K}^{+}$currents of muscarinic acetylcholine receptor subtypes in NG108-15 cclls. Naturc 335:355358.

Galper JB, Klein W, Catterall WA (1977) Muscarinic acetylcholine receptors in developing chick heart. J Biol Chem 252:8692-8699.

Gil DW, Wolfe BB (1985) Pirenzepine distinguishes between muscarinic receptor-mediated phosphoinositide breakdown and inhibition and adenylate cyclase. J Pharmacol Exp Ther 232:608-616.

Grant MP, Landis SC (1989) Nerve-target interactions in the developing sympathetic nervous system: development of an $\mathrm{m} 3$ muscarinic receptor. Soc Neurosci Abstr 15:1329.

Grant MP, Landis SC (1990) Coupling of muscarinic receptors in responsive and nonresponsive rat sweat glands. Soc Neurosci Abstr $16: 373$.

Grant MP, Landis SC (1991) Unexpected plasticity at autonomic junctions: cnvironmental regulation of neurotransmitter phenotype and receptor expression. Biochem Pharmacol 41:323-331.

Grant MP, Landis SC, Siegel RE (1991) The molecular and pharmacological properties of muscarinic cholinergic receptors expressed by rat sweat glands are unaltered by denervation. J Neurosci 11: 3763-3771.

Gratzner HG (1982) A new reagent for detection of DNA replication. Science 218:474-475.

Gu Y, Hall ZW (1988) Immunological evidence for a change in subunits of the acetylcholine receptor in developing and denervated rat muscle. Neuron 1:117-125.

Guest SJ, Hadcock JR, Watkins DC, Malbon CC (1990) $\beta_{1}$ and $\beta_{2}$ adrenergic receptor expression in differentiating 3T3-L1 cells. J Biol Chem 265:5370-5375.

Haddas RA, Landis CA, Putney JW (1979) Relationship between calcium release and potassium release in rat parotid gland. J Physiol (Lond) 291:457-465.

Halvorson SW, Nathanson NM (1984) Ontogenesis of physiological responsiveness and guanine nucleotide sensitivity of cardiac muscarinic receptors during chick embryonic development. Biochemistry 23:5813-5821.

Harden TK, Foster SJ, Perkins JP (1979) Differential expression of components of the adenyl cyclase system during growth of astrocytoma cells in culture. J Biol Chem 254:4416-4422.

Hayashi H, Nakagawa T (1963) Functional activity of the sweat glands of the albino rat. J Invest Dermatol 41:365-367.

Hunter DD, Nathanson NM (1984) Decreased physiological sensitivity mediated by newly synthesized muscarinic acetylcholine receptors in embryonic chick heart. Proc Natl Acad Sci USA 81:3582-3586.

Hunter DD, Nathanson NM (1986) Biochemical and physiological analyses of newly synthesized muscarinic acetylcholine receptors in cultured embryonic chicken cardiac cells. J Neurosci 6:3739-3748.

Jones SV, Barker JR, Buckley NJ, Bonner TI, Collins RM, Brann MR (1988) Cloned muscarinic receptor subtypes expressed in A9 cells differ in their coupling to electrical responses. Mol Pharmacol 34: $421-426$.

Kennedy WR, Sakuta M (1984) Collateral reinnervation of sweat glands. Ann Neurol 15:73-78.

Kennedy WR, Sakuta M, Quick DC (1984) Rodent eccrine sweat glands: a case of multiple efferent innervation. Neuroscience 11:741749.

Kubo T, Fukuda K, Mikami A, Maeda A, Takahashi H, Mishina M, Haga K, Ichiyama A, Kangawa K, Kojima M, Matsuo H, Hilrose T, Numa S (1986a) Cloning, sequencing and expression of complementary DNA encoding the muscarinic acetylcholine receptor. Nature 323:41 1-416.

Kubo T, Maeda A, Sugimoto K, Akiba I, Mikami A, Takahashi H, Haga T, Haga K, Ichiyama A, Kangawa K, Matsuo H, Mishina M, Hilrose T, Numa S (1986b) Primary structure of porcine cardiac muscarinic acetylcholine receptor deduced from the cDNA sequence. FEBS Lett 209:367-372.

Kullberg RW, Lentz TL, Cohen MW (1977) Development of myoto- 
mal neuromuscular junction in Xenopus lavevis: an electrophysiological and fine-structural study. Dev Biol 60:101-129.

Landis SC (1990) Target regulation of neurotransmitter phenotype. Trends Neurosci 13:344-350.

Landis SC, Fredieu JR (1986) Coexistence of calcitonin gene-related peptide and vasoactive intestinal peptide in cholinergic sympathetic innervation of rat sweat glands. Brain Res 377:177-181.

Landis SC, Keefe D (1983) Evidence for neurotransmitter plasicity in vivo: developmental changes in properties of cholinergic sympathetic neurons. Dev Biol 98:349-372.

Landis SC, Siegel RS, Schwab M (1988) Evidence for neurotransmitter plasticity in vivo. II. Immunocytochemical studies of rat sweat gland innervation during development. Dev Biol 126:129-140.

Leblanc G, Landis SC (1986) Development of choline acetyltransferase (CAT) in sympathetic innervation of rat sweat glands. J Neurosci 6:260-265.

Lechleiter J, Peralta E, Clapham D (1989) Diverse functions of muscarinic acetylcholine receptor subtypes. Trends Pharmacol Sci [suppl]10:34-38.

Lee W, Nicklaus KJ, Manning DR, Wolfe BB (1990) Ontogeny of cortical muscarinic receptor subtypes and muscarinic receptor-mediated responses in rat. J Pharmacol Exp Ther 252:482-490.

Liang BT, Hellmich MR, Neer EJ, Galper JB (1986) Development of muscarinic cholinergic inhibition of adenylate cyclase in embryonic chick heart. J Biol Chem 261:9011-9021.

Lowry OW, Rosebrough NJ, Farr AJ, Randell RJ (1951) Protein measurement with Folin phenol reagent. J Biol Chem 193:256-275.

Lunford JM, Talamo BR (1980) Beta-adrenergic and muscarinic receptors in developing rat parotid glands. J Biol Chem 255:4619-4627.

Lunford JM, Talamo BR (1983) Independent regulation of beta-adrenergic receptor and nucleotide binding proteins of adenylate cyclase. J Biol Chem 258:4831-4838.

Maeda A, Kubo T, Mishina M, Numa S (1988) Tissue distribution of mRNAs encoding muscarinic acetylcholine receptor subtypes. FEBS Lett 239:339-342.

Margiotta JF, Berg DK, Dionne V (1987) Cyclic AMP regulates the proportion of functional acetylcholine receptors on chick ciliary ganglion neurons. Proc Natl Acad Sci USA 84:8155-8159.

Marty A (1987) Control of ionic currents and fluid secretion by muscarinic agonists in exocrine glands. Trends Neurosci 10:373-377.

Mishina M, Takai T, Imoto K, Noda M, Takahashi T, Numa S, Methfessel C, Sakmann B (1986) Molecular distinction between fetal and adult forms of muscle acetylcholine receptor. Nature 321:406-411.

Moss SJ, Beeson DMW, Jackson JF, Darlison MG, Barnard EA (1987) Differential expression of nicotinic acetylcholine receptor genes in innervated and denervated chicken muscle. EMBO J 6:3917-3921.

Neher E, Marty A, Fukuda K, Kubo T, Numa S (1988) Intracellular calcium release mediated by two muscarinic receptor subtypes. FEBS Lett 240:88-94.
Nowakowski RS, Lewin SB, Miller MW (1989) Bromodeoxyuridine immunohistochemical determination of the lengths of the cell cycle and the DNA-synthetic phase for an anatomically defined population. J Neurocytol 18:311-318.

Pappano AJ, Loffelholz K (1974) Ontogenesis of adrenergic function and cholinergic neuroeffector transmission in chick embryo heart. J Pharmacol Exp Ther 191:468-478.

Peralta EG, Ashkenazi A, Winslow JW, Smith DH, Ramachandran J, Capon DJ (1987a) Distinct primary structures, ligand-binding properties and tissue specific expression of four human muscarinic acetylcholine receptors. EMBO J 6:3923-3929.

Peralta EG, Winslow JW, Peterson GL, Smith DH, Ashkenazi A, Ramachandran J, Sckimerlick MI, Capon DJ (1987b) Primary structure and biochemical properties of an $\mathbf{M}_{2}$ muscarinic receptor. Science 236:600-605.

Peralta EG, Ashkenazi A, Winslow JW, Ramachandran J, Capon DJ (1988) Differential regulation of PI hydrolysis and adenyl cyclase by muscarinic receptor subtypes. Nature 344:434-437.

Poggioli J, Putney JW (1982) Net calcium fluxes in rat parotid acinar cells. Pfluegers Arch 392:239-243.

Sato F, Sato K (1978) Secretion of a potassium-rich fluid by the secretory coil of the rat paw eccrine sweat gland. J Physiol (Lond) 274: $37-50$.

Schotzinger RJ, Landis SC (1988) Cholinergic phenotype developed by noradrenergic sympathetic neurons after innervation of a novel cholinergic target in vivo. Nature 335:637-639.

Schotzinger RJ, Landis SC (1990) Acquisition of cholinergic and peptidergic properties by sympathetic innervation of rat sweat glands requires interaction with normal target. Neuron 5:91-100.

Smith KE, Kessler JA (1988) Non-neuronal cell-conditioned medium regulates muscarinic receptor expression in cultured sympathetic neurons. J Neurosci 8:2406-2413.

Stevens LM, Landis SC (1987) Development and properties of the secretory response in rat sweat glands: relationship to the induction of cholinergic function in sweat gland innervation. Dev Biol 123:179 190.

Stevens LM, Landis SC (1988) Developmental interactions between sweat glands and the sympathetic neurons which innervate them: effects of delayed innervation on neurotransmitter plasticity and gland maturation. Dev Biol 130:703-720.

Trautman A, Marty A (1984) Activation of calcium-dependent potassium channels by carbamylcholine in rat lacrimal glands. Proc Natl Acad Sci USA 81:611-615.

Yodlowski ML, Fredieu JR, Landis SC (1984) Neonatal 6-hydroxydopamine treatment eliminates cholinergic sympathetic innervation and induces sensory sprouting in rat sweat glands. J Neurosci 4:15351548. 